\title{
An Economic Study on Consumer Satisfaction towards Online Shopping in Madurai City
}

\section{OPEN ACCESS}

Manuscript ID:

COM-2021-09023832

Volume: 9

Issue: 2

Month: April

Year: 2021

E-ISSN: 2582-6190

Received: 13.12.2020

Accepted: 17.03.2021

Published: 01.04.2021

Citation:

Srinivasan, KR, and

TP Ramprsad. "An

Economic Study on

Consumer Satisfaction towards Online Shopping in Madurai City." ComFin Research, vol. 9, no. 2, 2021, pp. 57-63.

DOI:

https://doi.org/10.34293/ commerce.v9i2.3832

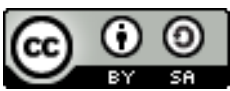

This work is licensed under a Creative Commons Attribution-ShareAlike 4.0 International License

\section{K.R. Srinivasan}

Assistant Professor \& Head, Department of Economics

Sourashtra College (A), Madurai, Tamil Nadu, India

\section{T.P. Ramprasad}

Assistant Professor, Department of Commerce \& Research Centre

Sourashtra College (A), Madurai, Tamil Nadu, India

\section{Abstract}

Now-a-days developing countries like India converting their traditional marketing strategy into modern electronic mode or online marketing us people in India also felt comfortable in online shopping, Madurai is a business city where can find lot of business emerging here and there. People in Madurai are considerably tradition in their virtues. This study has been taken to analyse the satisfaction level of the customer towards online shopping; objective of the study is to find satisfaction level and the factor influencing online shopping. Using simple random sampling method, data has been collected from 45 respondents from Madurai city. Data analysed with the help of SPSS software.

Keywords: Online shopping, Madurai, Consumer satisfaction

\section{Introduction}

Nowadays, online shopping could be a new trend practiced by each individual due to its options. Online looking could be a pc-based looking through with the assistance of net and computer applications; on-line looking could be a revolution of latest business trends. It provides monumental employment chance. Online-looking customers choosing their most well-liked merchandise or services within the user interface application with the assistance of a monitor or screen. Raised usage of the net is additionally one in every one of the explanations for the expansion of on-line looking. On-line looking provides higher expertise to the client and it initiates and attracts each client. It saves time, money, energy, human contact, offers discounts, wide choice of merchandise, wide word services, user friendly and convenient. The dynamical desires and preferences of shoppers, amendment in technologies, and also the need of the business organizations to form sensible revenues and to enhance the client base crystal rectifier to the evolution and existence of on-line looking. Plenty of shoppers are now-a-days as the internet provides plenty of benefits to shoppers. It saves time and allows them to avoid the crowd. Bound merchandise ar well cheaper and permit customers to get product from anyplace, anytime within the world. 


\section{Statement of the Problem}

In low, competitive market, retention of the client is a simple task. However, this is often not true in online looking, as customers have wide chance to decide on the net portals wherever merchandise are offered at a low worth, delivery of products at a shorter span of your time, discounts offered, etc.. Therefore, client retention could be a difficult task for all $\mathrm{E}$ commerce operators. Thus, client retention alone depends on customer's satisfaction. Customers' WHO purchase merchandise on-line is also happy due to and quality of knowledge offered in internet portals, Quality of products delivered, merchandise matching with the merchandise displayed on websites, worth charged for the merchandise, time is taken for delivery etc., Hence during this study an attend has been main to check the client satisfaction towards on-line looking.

\section{Objectives of the Study}

- To know about online shopping or evaluation.

- To analyze the demographic detail of the responder.

- To examine the purchasing pattern of the customer, preference of online shopping service provider, and the source of awareness towards online shopping.

- To analyse the customer's satisfaction of online shopping.

\section{Review of Literature}

Rashant Singh (2014), in his study on Consumer's Buying Behaviour Towards Online Shopping, the main aim of study was to examine and analyze the consumer 's buying behavior pattern towards online shopping in Lucknow. The research is based on both primary data and secondary data. The total sample sizes of 40 were collected through a questionnaire by using a convenient sampling method, the outcome of the study is the greatest number of users are happy with online shopping and mainly interested in buying online apparel.

Chirag Parmar, (2015), The main objective of the research is to study, especially the major option for payments in online shopping. There are several payment options in online purchasing such as credit card, debit card, cash on delivery, EMI option, gift voucher or wallet Rs. of the particular site. To this end, a survey was conducted and the 120 questionnaires were distributed among the people of different markets and the general public in Bikaner. The replies have been analyzed by table analysis. The results of the study reveal that on-line shoppers in India are significantly affected by various payment options, which are described above. The study results could be further used by the researchers and practitioners for conducting future studies in a similar area.

Mohammad Toufiqur Rahman (2015) indicated that online shoppers are variety lovers, but at the same time, they are also cautious about the price and time that they spent shopping. Online shopping saves time comparing to a traditional retail stores. Maximum respondent relies on price and their own experience as the basis of the quality judgment of items in online shopping.. So far as payment options are concerned, online shopping offers different payment options like cash on delivery or payment through internet banking or payment by debit card or credit card etc. But the majority of the buyers preferred cash on delivery facility.

\section{Research Methodology}

This study descriptive in nature. Data has been collected through primary \& secondary data. Primary data was collected using a structure interview schedule; secondary data was collected from books, journals, newspapers, other published sources, and websites.

\section{Sample Design}

The study is entitled 'A study on consumer satisfaction towards online shopping in Madurai city'. A survey was conducted among 45 respondents by using structured interview schedule method.

\section{Data Collection}

The fieldwork of study was collected from various parts of Madurai city. Distribution methodology followed in data collected is given under:

Total no of questionnaire distributed: 55

Total number of questionnaire received from respondents: 47

No of questionnaire discarded: 8

The total no of a sample taken for study is: 45 
Framework of Analysis

To measure the consumer satisfaction towards online shopping in Madurai city following statistical tools are used with the help of SPSS package.

Percentage analysis

Weighted average score ranking

One-way ANOVA.

\section{Limitations of the Study}

The study is confined to Madurai district only.

The study is based upon the consumer behaviors of online shopping

The data collected for the research is primary and secondary data given by the respondents

Due to storage of time and other constrain, the study has been limited to 45 respondents only.

\section{Percentage Analysis and Weighted Average Score Ranking}

Table 1: Gender wise Classification

\begin{tabular}{|c|l|c|c|}
\hline S. No & Options & $\begin{array}{c}\text { No of } \\
\text { Respondents }\end{array}$ & Percentage \\
\hline 1 & Female & 33 & 73.3 \\
\hline 2 & Male & 12 & 26.7 \\
\hline \multicolumn{2}{|c|}{ Total } & 45 & 100 \\
\hline
\end{tabular}

Interpretation: Table 1 is observed that 73.3 percent of respondents are female 26.7 percent of the respondents are male. The majority of the respondents belong to the category of Female.

Table 2: Age wise Classification

\begin{tabular}{|c|l|c|c|}
\hline S. No & Options & $\begin{array}{c}\text { No of } \\
\text { Respondents }\end{array}$ & Percentage \\
\hline 1 & $18-25$ & 13 & 28.9 \\
\hline 2 & $26-33$ & 22 & 48.9 \\
\hline 3 & $34-41$ & 4 & 8.9 \\
\hline 4 & Above 41 & 6 & 13.3 \\
\hline \multicolumn{2}{|c|}{ Total } & 45 & 100 \\
\hline
\end{tabular}

Interpretation: From the table 2, it is observed that 28.9 percent of respondents belongs to the age group of $18-25,48.9$ percent of the respondents belong to the age group of 26-33, 8.9 percent of the respondent belong to the age group of 34-41, 13.3 percent of the respondents belong to the age group of above 41 . The majority of the respondents belong to the category of 26-33. since there is the majority of the respondent's income-earning comes under this group has more responsibility on household.

Table 3: Education Qualification

\begin{tabular}{|c|l|c|c|}
\hline $\begin{array}{c}\text { S. } \\
\text { No }\end{array}$ & \multicolumn{1}{|c|}{ Options } & $\begin{array}{c}\text { No. of } \\
\text { Respondents }\end{array}$ & Percentage \\
\hline 1 & School level & 8 & 17.8 \\
\hline 2 & Under graduate & 12 & 26.7 \\
\hline 3 & Post graduate & 23 & 51.1 \\
\hline 4 & Professional & 2 & 4.4 \\
\hline \multicolumn{2}{|c|}{ Total } & 45 & 100 \\
\hline
\end{tabular}

Interpretation: From Table 3 is observed that 51.1 percent of respondents belongs to the educational qualification of Postgraduate, 26.7 percent of the respondents belong to the educational qualification of Undergraduate, 17.87 percent of the respondents belong to the educational qualification of School level, 4.487 percent of the respondents belong to the educational qualification of Professional. The majority of the respondents belong to the category of Postgraduate.

Table 4: Occupation

\begin{tabular}{|c|l|c|c|}
\hline $\begin{array}{c}\text { S. } \\
\text { No }\end{array}$ & \multicolumn{1}{|c|}{ Option } & $\begin{array}{c}\text { No. of } \\
\text { Respondents }\end{array}$ & Percentage \\
\hline 1 & Student & 12 & 26.7 \\
\hline 2 & Private employee & 14 & 31.1 \\
\hline 3 & Govt employee & 15 & 33.3 \\
\hline 4 & Home maker & 4 & 8.9 \\
\hline \multicolumn{2}{|c|}{ Total } & 45 & 100 \\
\hline
\end{tabular}

Interpretation: From Table 4 is observed that 33.3 percent of the respondents belongs to the occupation of Government employee, 31.1 percent of the respondents are belong to the occupation of Private employee, 26.7 percent of the respondents are belong to the occupation of Student, 8.9 percent of the respondents are belong to the occupation of Homemaker. The majority of the respondents belong to the category of Govt employee.

Table 5: Marital Status

\begin{tabular}{|c|l|c|c|}
\hline S. No & Options & $\begin{array}{c}\text { No. of } \\
\text { Respondents }\end{array}$ & Percentage \\
\hline 1 & Married & 35 & 77.8 \\
\hline 2 & Unmarried & 10 & 22.2 \\
\hline \multicolumn{2}{|c|}{ Total } & 45 & 100 \\
\hline
\end{tabular}


Interpretation: From Table 5 is observed that 77.8 percentage of respondents belongs to the Marital status of Married, 22.2 percentage of respondents are belong to the Marital status of Unmarried. Majority of the respondents belong to the category of Married.

Table 6: Income

\begin{tabular}{|c|c|c|c|}
\hline S. No & Option & $\begin{array}{c}\text { No. of } \\
\text { respondents }\end{array}$ & Percentage \\
\hline 1 & Below 10000 & 13 & 28.9 \\
\hline 2 & $10000-20000$ & 14 & 31.1 \\
\hline 3 & $20000-30000$ & 14 & 31.1 \\
\hline 4 & Above 30000 & 4 & 8.9 \\
\hline \multicolumn{2}{|c|}{ Total } & 45 & 100 \\
\hline
\end{tabular}

Interpretation: From Table 6 is observed that 31.1 percent of the respondents are belong to the income of 10000-20000 and 20000-30000, 28.9 percent of the respondents are belong to the income of Below $10000,8.9$ percent of percent of the respondents are belong to the income group of Above 30000 . Majority of the respondents belong to the categories of 10000-20000 and 20000-30000.

Table 7: Purchase Pattern of the Customer

\begin{tabular}{|c|l|c|c|}
\hline $\begin{array}{c}\text { S. } \\
\text { No }\end{array}$ & \multicolumn{1}{|c|}{ Options } & $\begin{array}{c}\text { No of } \\
\text { Respondents }\end{array}$ & Percentage \\
\hline 1 & Once a month & 15 & 33.3 \\
\hline 2 & Twice a month & 19 & 42.2 \\
\hline 3 & Once a year & 7 & 15.6 \\
\hline 4 & Twice a year & 4 & 8.9 \\
\hline \multicolumn{2}{r|}{ Total } & 45 & 100 \\
\hline
\end{tabular}

Interpretation: From Table 7 observed 42.2 percent of the respondents are belong to the frequency of Twice a month, 33.3 percent of the respondents are belong to the frequency of Once a month, 15.6 percent of the respondents are belonging to the frequency of Once a year, 8.9 percent of respondents are belong to the frequency of Twice a year. Majority of respondents belong to category of Twice a month.

Table 8: Source of Awareness

\begin{tabular}{|c|l|c|c|}
\hline $\begin{array}{c}\text { S. } \\
\text { No }\end{array}$ & \multicolumn{1}{|c|}{ Options } & $\begin{array}{c}\text { No. of } \\
\text { Respondents }\end{array}$ & Percentage \\
\hline 1 & Through newspaper & 8 & 17.8 \\
\hline 2 & Social media & 18 & 40.0 \\
\hline 3 & Refer with friends & 14 & 31.1 \\
\hline
\end{tabular}

\begin{tabular}{|c|c|c|c|}
\hline 4 & Television & 5 & 11.1 \\
\hline \multicolumn{2}{|c|}{ Total } & 45 & 100 \\
\hline
\end{tabular}

Interpretation: From Table 8 is observed that 40 percent of the respondents belongs to source of awareness of Social media, 31.1 percent of the respondents are belong to the source of awareness of Refer with friends, 17.8 percent of the respondents belongs to source of awareness of Through newspaper, 11.1 percent of the respondents are belong to source of awareness of Television, majority of the respondents belong to the category of Social media.

Table 9: Shopping

\begin{tabular}{|c|l|c|c|}
\hline $\begin{array}{c}\text { S. } \\
\text { No }\end{array}$ & \multicolumn{1}{|c|}{ Options } & $\begin{array}{c}\text { No. of } \\
\text { Respondents }\end{array}$ & Percentage \\
\hline 1 & Electronic & 21 & 46.7 \\
\hline 2 & Households & 16 & 35.6 \\
\hline 3 & Life Style Products & 5 & 11.1 \\
\hline 4 & $\begin{array}{l}\text { Books/Stationaries/ } \\
\text { Office supplies etc. }\end{array}$ & 3 & 6.7 \\
\hline \multicolumn{2}{|c|}{ Total } & 45 & 100 \\
\hline
\end{tabular}

Interpretation: From the Table 9, is observed that 46.7 percent of the respondents belongs to Product purchased of Electronic, 35.6 percent of the respondents are belong to Product purchased of Household, 11.1 percent of the respondents are belong to Product purchased of household products like grocery, clothes, handbags, toys etc., 6.7 percent of the respondents belong to Product purchased of Books. Majority of the respondents belong to the category of Electronics like refrigerator, television, cell phone, laptops, and earphones etc.

Table 10: Factor Influencing Online Shopping

\begin{tabular}{|c|l|c|c|}
\hline $\begin{array}{c}\text { S. } \\
\text { No }\end{array}$ & \multicolumn{1}{|c|}{ Options } & $\begin{array}{c}\text { No. of } \\
\text { Respondents }\end{array}$ & Percentage \\
\hline 1 & Save time & 21 & 46.7 \\
\hline 2 & Better price & 15 & 33.3 \\
\hline 3 & More variety & 6 & 13.3 \\
\hline 4 & Flexible shipping & 3 & 6.7 \\
\hline \multicolumn{2}{r|}{ Total } & 45 & 100 \\
\hline
\end{tabular}

Interpretation: From table 10 observed that 46.7 percent of the respondent using online shopping because it saves time, 33.3 percent of the respondent prefer online shopping because online websites offer 
better price then traditional shops, 13.3 percent of the respondents prefers online shopping because of availability of a variety of products. Majority of the respondents buying products online because it saves time.

Table 11: The Level of Satisfaction towards Online Shopping

\begin{tabular}{|c|l|c|c|c|c|c|c|c|}
\hline $\begin{array}{c}\text { S. } \\
\text { No }\end{array}$ & \multicolumn{1}{|c|}{ Dimension } & $\begin{array}{c}\text { Highly } \\
\text { Satisfied }\end{array}$ & Satisfied & Neutral & Dissatisfied & $\begin{array}{c}\text { Highly } \\
\text { Dissatisfied }\end{array}$ & Total & Rank \\
\hline 1 & Quality & $10(22.2 \%)$ & $20(44.4 \%)$ & $11(24.4 \%)$ & $4(8.9 \%)$ & $0(0 \%)$ & 171 & 1 \\
\hline 2 & Colour difference & $8(17.8 \%)$ & $14(31.1 \%)$ & $15(33.3 \%)$ & $5(11.1 \%)$ & $3(6.7 \%)$ & 154 & 3 \\
\hline 3 & $\begin{array}{l}\text { Delivery within } \\
\text { tipulated time }\end{array}$ & $8(17.8 \%)$ & $12(26.7 \%)$ & $21(46.7 \%)$ & $2(4.4 \%)$ & $2(4.4 \%)$ & 157 & 2 \\
\hline 4 & Offer and discount & $4(8.9 \%)$ & $7(15.6 \%)$ & $16(35.6 \%)$ & $13(28.9 \%)$ & $5(11.1 \%)$ & 127 & 4 \\
\hline 5 & $\begin{array}{l}\text { Delivery of the } \\
\text { specified product }\end{array}$ & $2(4.4 \%)$ & $13(28.9 \%)$ & $9(20.0 \%)$ & $17(37.8 \%)$ & $4(8.9 \%)$ & 127 & 4 \\
\hline \multicolumn{7}{|c|}{ Total } \\
\hline
\end{tabular}

Interpretation: The opinion of satisfaction level regarding Product buying online shopping indicates the maximum statement score of 171. Second, third, fourth are 157, 154,127, 127, respectively. This is very easy to read and informative and useful. It is confirmed that most respondents prefer online shopping because of the quality of the service and goods offered.

\section{Relationship between Gender and Satisfaction towards Online Shopping}

To test there is any relationship between Gender and satisfaction towards online shopping. One-way ANOVA has been applied to test the following hypothesis.

"There is no significant relationship between gender of the respondent and the satisfaction level of the respondents towards online shopping."

Table 12: Result of the One-way ANOVA Test

\begin{tabular}{|l|c|c|c|}
\hline \multicolumn{1}{|c|}{ Dimension } & F & Sig & Result \\
\hline Quality & 3.153 & 0.083 & NS \\
\hline Colour difference & 0.852 & 0.361 & NS \\
\hline $\begin{array}{l}\text { Delivery within stipulated } \\
\text { time }\end{array}$ & 1,758 & 0.192 & NS \\
\hline Offer and discounts & 0.749 & 0.392 & NS \\
\hline $\begin{array}{l}\text { Delivery of the specified } \\
\text { product }\end{array}$ & 0.002 & 0.968 & NS \\
\hline
\end{tabular}

Interpretation: Regarding the overall Desire level, the value of the level of significance is greater than 0.05 the null hypothesis is accepted. Since there is no significant relationship between the gender of the respondent and the satisfaction level of the respondents towards online shopping, it is concluded that gender has no influence on the level of satisfaction.

\section{Relationship between Age and Satisfaction towards Online Shopping}

To test there is any relationship between age and satisfaction towards online shopping. One-way ANOVA has been applied to test the following hypothesis

"There is no significant relationship between age of the respondent and the satisfaction level of the respondents towards online shopping."

Table 13: Result of the One-way ANOVA Test

\begin{tabular}{|l|c|c|c|}
\hline \multicolumn{1}{|c|}{ Dimension } & F & Sig & Result \\
\hline Quality & 1.030 & 0.389 & NS \\
\hline Colour difference & 10.120 & 0.000 & NS \\
\hline $\begin{array}{l}\text { Delivery within } \\
\text { stipulated time }\end{array}$ & 4.062 & 0.013 & S \\
\hline Offer and discounts & 2.321 & 0.089 & NS \\
\hline $\begin{array}{l}\text { Delivery of the specified } \\
\text { product }\end{array}$ & 0.822 & 0.489 & NS \\
\hline
\end{tabular}

Interpretation: With regards to overall satisfaction level and age, the null hypothesis was accepted. Hence there is no significant relationship between age and satisfaction level. Since there is no significant relationship between the age of the respondent and the satisfaction level of the respondents towards 
online shopping, hence it is concluded that age has no influence on the level of satisfaction except delivery of product on time.

\section{Relationship between Educational Qualification and Satisfaction towards Online Shopping}

To test there is any relationship between the educational qualification and satisfaction towards online shopping. One-way ANOVA has been applied to test the following hypothesis

"There is no significant relationship between the educational qualification of the respondent and the satisfaction level of the respondents towards online shopping."

Table 14: Result of the one-way ANOVA Test

\begin{tabular}{|l|c|c|c|}
\hline \multicolumn{1}{|c|}{ Dimension } & F & Sig & Result \\
\hline Quality & 4.051 & 0.013 & S \\
\hline Colour difference & 2.227 & 0.100 & NS \\
\hline $\begin{array}{l}\text { Delivery within } \\
\text { stipulated time }\end{array}$ & 14.721 & 0.000 & NS \\
\hline Offer and discounts & 10.310 & 0.000 & NS \\
\hline $\begin{array}{l}\text { Delivery of the } \\
\text { specified product }\end{array}$ & 7.271 & 0.001 & S \\
\hline
\end{tabular}

Interpretation: Regarding overall satisfaction level and educational qualification, the null hypothesis is accepted since there is no significant relationship between educational qualification and the satisfaction level. Hence it is concluded that education qualification has no influence on satisfaction except the quality of the product and the delivery of the product on time.

\section{Relationship between Occupation and Satisfaction towards Online Shopping}

To test there is any relationship between the occupation and satisfaction towards online shopping. One-way ANOVA has been applied to test the following hypothesis

"There is no significant relationship between the occupation of the respondent and the satisfaction level of the respondents towards online shopping."

Table 15: Result of the one-way ANNOVA Test

\begin{tabular}{|l|c|c|c|}
\hline \multicolumn{1}{|c|}{ Dimension } & F & Sig & Result \\
\hline Quality & 1.220 & 0.314 & NS \\
\hline Colour difference & 0.537 & 0.660 & NS \\
\hline
\end{tabular}

\begin{tabular}{|l|c|c|c|}
\hline $\begin{array}{l}\text { Delivery within } \\
\text { stipulated time }\end{array}$ & 0.284 & 0.837 & NS \\
\hline Offer and discounts & 3.515 & 0.023 & S \\
\hline $\begin{array}{l}\text { Delivery of the specified } \\
\text { product }\end{array}$ & 2.052 & 0.122 & NS \\
\hline
\end{tabular}

Interpretation: With regards to overall satisfaction level and occupation, the null hypothesis accepted since there is no significant relationship between occupation and the satisfaction level. Hence it is concluded that occupation has no influence on satisfaction except offers provided by websites.

\section{Relationship between Income and Satisfaction towards Online Shopping}

To test there is any relationship between income and satisfaction towards online shopping. One-way ANOVA has been applied to test the following hypothesis.

"There is no significant relationship between income of the respondent and the satisfaction level of the respondents towards online shopping."

Table 16: Result of the one-way ANOVA Test

\begin{tabular}{|l|c|c|c|}
\hline \multicolumn{1}{|c|}{ Dimension } & F & Sig & Result \\
\hline Quality & 2.474 & 0.075 & NS \\
\hline Colour difference & 1.375 & 0.264 & NS \\
\hline $\begin{array}{l}\text { Delivery within } \\
\text { stipulated time }\end{array}$ & 0.680 & 0.569 & NS \\
\hline Offer and discounts & 1.306 & 0.285 & NS \\
\hline $\begin{array}{l}\text { Delivery of the specified } \\
\text { product }\end{array}$ & 2.877 & 0.048 & S \\
\hline
\end{tabular}

Interpretation: With regards to overall satisfaction level and income, the null hypothesis accepted since there is no significant relationship between income and the satisfaction level. Hence it is concluded that income has no influence on satisfaction except delivery of the specific goods orders by the customer.

\section{Findings}

- The majority of the respondents belong to the category of Female.

- The majority of the respondents belong to the category of 26-33. since there is the majority of the respondent's income-earning comes under this group has more responsibility on the household. 
- The majority of the respondents belong to the category of Postgraduate.

- The majority of the respondents belong to the category of Govt employee.

- The majority of the respondents belong to the category of Married.

- The majority of the respondents belong to the categories of 10000-20000and 20000-30000.

- The majority of the respondents belong to the category of Married.

- The majority of the respondents belong to the category of Twice a month.

- Majority of the respondents buying products online because it saves time.

- The majority of the respondents prefer online shopping because of the quality of the service and goods offered.

- Gender has no influence on the level of satisfaction.

- Age has no influence on the level of satisfaction except delivery of product on time.

- Occupation has no influence on the level of satisfaction except offers provided by websites.

- Education qualification has no influence on satisfaction except the quality of the product and the delivery of the product on time.

- Income has no influence on the level of satisfaction except delivery of the specific goods orders by the customer.

\section{Conclusion}

Online shopping enables various offers and various products to their customers; they provide timely delivery of the desired product at their doorsteps. It attracts more female customers, changing the preference and taste of the customers. They are expecting a wide range of products to select within the place where they are. Online shopping portals and applications satisfy them by offering enormous services and discounts. It is a comfortable mode of buying products for their house hoods and electronics for their house using online shopping. It is s concluded that online shopping is maximum preferred by the customer because of the quality of services offered by online portals like amazon, flip kart, paytm mall etc.,

\section{References}

Manjula Bai, H. "Perception Analysis of Online Shopping: A Case Study of amazon.com." Shanlax International Journal of Commerce, vol. 8, no. 2, 2020, pp. 53-60.

Muruganantham, S., et al. "A Study of Consumer Satisfaction towards Online Shopping with Special Reference to Coimbatore City." International Journal of Applied Research, vol. 3, no. 12, 2017, pp. 171-174.

Parmar, Chirag. "A Comparative Study on Various Payment Options in Online Shopping." International Journal on Recent and Innovation Trends in Computing and Communication, vol. 3, 2015, pp. 2433-2436.

Rahman, Mohammad Toufiqur. "Customers' Attitude towards Online Shopping: The Case of Bangladesh." World Journal of Social Sciences, vol. 6, no. 2, 2016, pp. 82-91.

Singh, Prashant. "Consumer 's Buying Behavior towards Online Shopping: A Case Study on Flipkart.com Users in Lucknow City." Abhinav - Journal of Research in Commerce and Management, 2014.

Sundaramoorthy, S., and A. Abirami. "A Study on Customer Satisfaction towards Online Shopping in Tenkasi Town." Shanlax International Journal of Commerce, vol. 4, no. 1, 2016, pp. 10-15.

Tandon, Urvashi, et al. "Analyzing Customer Satisfaction: Users Perspective towards Online Shopping." Nankai Business Review International, vol. 8, no. 3, 2017, pp. 266-288.

\section{Author Details}

Dr. K.R. Srinivasan, Assistant Professor \& Head, Department of Economics, Sourashtra College (A), Madurai, Tamil Nadu, India, Email ID: kumbasrini@gmail.com

Dr. T.P. Ramprasad, Assistant Professor, Department of Commerce \& Research Centre, Sourashtra College (A), Madurai, Tamil Nadu, India 